Јелена Пилиповић

Филолошки факултет

Универзитет у Београду

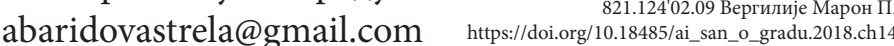

\title{
САН О РИМУ - ВИЗИЈА ИДЕАЛНОГ ГРАДА \\ У ВЕРГИЛИЈЕВОМ ДЕЛУ
}

Вергилијево поетско ткање чврсто проткива визија идеалног Рима, која се, на Андрићевом трагу, може назвати сан о Риму. Од прве Еклоїе до крајњих стихова Енеиge садржај појма сан се мења, но и значење речи Рим. Блиставу слику Рима као сотериолошког простора у Еклоїама смењује сновиђење о бескрајном разастирању Рима у простору и у времену, да би се у Шестом певању Енеияе развило ониричко-есхатолошко откровење Рима као метафизичког средишта света. Иако је визија идеалног Града Рима све разбокоренија и разгранатија, она истодобно и све снажније расте ка иреалном. Овај прилог ће покушати да оцрта те многослојне творачке метаморфозе.

Кључне речи: идеал, идеолошко, ониричко, есхатологија, иреално, сотериолошки херој, П. Вергилије Марон, Рутилије Клаудије Наматијан.

\section{1. Увод}

Реч Рим, Roma, умногоме и данас чува дисемију која ју је у одликовала у древнини, када је била име и града на Тибру и државе која се простирала великим делом земног шара. Овом, тополошком, двозначју Публије Вергилије Марон надграђује сасвим другачијим удвајањем смисла: велики августовски песник реч 
Рuм разастире до крајњих граница овостраности и до крајњих висова оностраности. Такво разастирање заправо је сневање. Распрострт до крајњих предела са географских мапа, узнесен до крајњих тачака из тео-есхатолошких схема, разливен у времену: вергилијевски сан о Риму је књижевни конструкт - како тече? Има ли своју динамику? Игра ли се игре скривања и откривања? Поседује ли сопствене поетске механизме? Оглед који се нуди читаоцу покушаће да одговори на та питања једним видом компаративне херменеутике који ће у Вергилијево поетско сневање призвати сасневача. Античка књижевност, наиме, зна за многе песнике Рима, који су многолики Град над градовима из разних углова осветљавали и у своме стваралачком језику на разне начине констируисали: славећи га, исмевајући, оплакујући. Или само у њему уживајући. Од свих њих за вергилијевског сасневача бирам Рутилија Клаудија Наматијана, ${ }^{1}$ мало знаног списатеља који на заласку античке културе, у неком часу након 416. године н.е, исписује дугу поему о своме повратку из престонице, већ самртничког, царства у Галију, De Reditu Suo. ${ }^{2}$ Чему овај позни сасневач? Поема $O$ своме йоврайку умногоме је далеки одјек Вергилијевог конструкта Рима: ${ }^{3}$ одјек који није само удаљен у времену, већ и у мисаоности и културалном озрачју - стога се многи полисемични, слојевити и сложени аспекти вергилијевског Рима поједно-

1 * Рад је настао у оквиру пројекта бр. 177001 Министарства за просвету, науку и технолошки развој.

О биографији овог позноантичког песника и великодостојника, као и околностима настанка поеме вид. Norwood 1947; Будимир - Флашар 1991: 625.

2 Спис припада корпусу позноантичких песама у част Рима, међу којима се могу препознати знатне сличности и карактеристични поступци - о томе Roberts 2001.

3 За целовиту анализу интертекстуалних односа два песника вид. Filoche - Boëls-Janssen 2007. 
Сан о Риму - визија идеалног Града у Вергилијевом делу 327

стављују у рутилијевском Рuмy, али и на друге начине постају ближи савременом читаоцу. У своме сасневачу велики сневач Рима може наћи метафорички међустепеник којим се из света обичног језика лакше прелази у свет Вергилијевог вишезначја.

Оглед се неће запутити ка свим видовима Рима који су створени у Вергилијевом делу, већ само кроз оне конститутивне за саму слику града, међу којима се одважујем да издвојим три: аркадијски Рим, Рим-бескрај, елизијски Рим.

\section{2. Аркадијски Рим}

Рим улази у Вергилијеву поезију на самом њеном почетку, у првој поеми Еклоїa. У самом језгру идиличног простора, који се кроз ову збирку постепено развија у велики тополошки конструкт песника из Мантове, Аркаgujy, находи се наизглед урбани ентитет:

Urbem, quam dicunt Romam, Meliboee, putaui stultus ego huic nostrae similem, quo saepe solemus pastores ouium teneros depellere fetus: sic canibus catulos similis, sic matribus haedos noram, sic paruis componere magna solebam: uerum haec tantum alias inter caput extulit urbes, quantum lenta solent inter uiburna cupressi. Град што назива се Рим, мишљах, у глупости својој, Налик да граду је нашем, Мелибеју, ми пастири Оваца младунчад нежну у који гонимо често. Да псетанце пса је одслик, налик да мајци је јаре Знадох - велико по малом замишљао ја сам негда. Ал' у ствари, над градовима другим главу толико Уздиже Рим, колико се над акантовим жбуњем кипариси дижу. ${ }^{4}$

4 Еклоїе 1.20-26. Мој превод. 
Рим који се диже налик стиаблу кийариса први је метафорички израз трансонтичке вертикале која ће обележити Вергилијево дело. Утолико се може рећи да се и над Аркадијом, као и над свим потоњим вергилијевским просторима, уздиже Рим, као истовремено и овострани и онострани ареал. Престоница није, међутим, само парадигма узвишености, већ, надасве, место у коме столује један особени $\delta o \bar{\imath}$ :

O Meliboee, deus nobis haec otia fecit: namque erit ille mihi semper deus; illius aram saepe tener nostris ab ouilibus imbuet agnus. Ille meas errare boues, ut cernis, et ipsum ludere, quae uellem, calamo permisit agresti. Доколицу и живот тај, Мелибеју, мени је дао Бог: вавек за мене бог ће остати он.

Нежна јагњад из обора мојих његов жртвеник крвљу Обливаће често: јер што ми стада спокојно пасу,

Што се поигравам простом свиралом од трске, какав пожелим

Извијам на њој глас - само његов је дар. ${ }^{5}$

Млаgи $\delta о \overline{~ с п а д а ~ у ~ н а ј к о н т р о в е р з н и ј е ~ ф и г у-~}$ ре Вергилијеве поезије, отвара се ка низу алегоријских и симболичких интерпретација, а сасвим сигурно представља први појавни облик најважнијег песниковог сотериолошког конструкта: божанског владара, који ће кроз три дела, Еклоїе, Георіике и Eнеugy, узети на себе антропоморфне, теоморфне, чак и зооморфне, као и идејне облике. Отелотворава се недвосмислено у краљу йчела и у Енеји, али учествује и у сазначјима која обележавају божанскої дечака Чейврйе еклоїе, Орфеја,

5 Еклоїе 1.6-10. Мој превод. 
Сан о Риму - визија идеалног Града у Вергилијевом делу 329

Аристаја, као и низ ликова Eнеиgе (Јупитера, Асканија, Евандра...) У првој песми Еклоїа испољавају се његове суштаствене одлике, које ће претрајати кроз сва оваплоћења: додир са трансцендентним, припадност Риму, и као геополитичком и као метафизичком Граду, и, најзад, улога спаситеља.

Саучествовање млаgоі̄ бoīa у трансцендентности није дословно, али није ни пука песничка метафора: лик флуктуира између овостраности и оностраности, својим дејством и култом показује се као божанство, а релативношћу и недореченошћу божанственост му се оспорава. Стога није чврста онтолошка датост, већ последица благодати коју млаgић обезбеђује: боголикост происходи из функције чувара-спаситеља. Први облик вергилијевског сна о Риму, аркадијски ірpag-кийарис, већ у пуној мери показује оно што ће бити основна одлика свих облика вергилијевског сневања: реални град се симбиотички спаја са тополошким и са сотериолошким конструктом. Рим је обитавалиште божанскої, место моћи очувања и обнављања вредности, а тиме и језгро трансформације света - не у нови космос, већ у ванвремену космичност.

\section{3. Рим-бескрај}

Појава Рима у Енеиgи заогрнута је копреном профетског говора и неодвојива од примордијалних метафизичких вредности: вечности и бескрајности:

...cernes urbem et promissa Lavini moenia, sublimemque feres ad sidera caeli magnanimum Aenean; neque me sententia vertit. 
... видећеш град и лавинијски бедем,

ко што обећах, и дићи ћеш једном до небеских звезда мегдан-јунака Енеју...

Вредносна надмоћ Рима у односу на све остале градове, наговештена поређењем у Првој еклоги, сада се јасно разграњава на бесконачност и у времену и у простору, али се и садржај Рима као тополошког конструкта мења - није више у питању само урбани ентитет, већ и етнички: у њему се дају разлучити Рим-град, Roma-urbs, и Рим-народ, Roma-gens:

... Romulus excipiet gentem, et Mavortia condet moenia, Romanosque suo de nomine dicet. His ego nec metas rerum nec tempora pono; imperium sine fine dedi.

...Ромул ће преузети вођство, те бедеме, достојне Марса, саздати римске, а своје ће име и народу дати.

Њима ни временске међе, нит границе постављам какве: бескрајну дадох им власт. ${ }^{7}$

Рим-град, Roma-urbs, предочава се унутар сложене поредбене мреже која испуњава значајан део спева: њоме се плете низ различитости које Рим супротстављају Троји и Картагини. Унутар епског света Енеиgе, Рим је иреалан, Троја и Картагина реално бивствују, премда је њихова урбана структура прилично скоковито описана, а понекад и само наговештена. Картагински храмови, позоришта и тргови који се још увек зидају 8 представљају најцеловитију слику града у Eнеugu:

6 Eнеияа 1.258-260. Прев. М. Пакиж.

7 Енеияа 1.276-279. Прев. М. Пакиж.

8 Eнейа $4.260-261$. 
Сан о Риму - визија идеалног Града у Вергилијевом делу 331

иако тек настаје Дидонин град моћно израста на читалачком обзорју својом тврђавом, високим зградама, капијама, путевима, кулама, крововима, луком, театром и амфитеатром (1.420-438). Опис Јунониног храма, средишњег сакралног објекта у растућем граду, толико је минуциозан да започиње од степеница, читаоца води преко бронзаног прага и бронзаних двери, да би пред њим развио „огромну слику“ (1.464), редак пример екфразе наративног сликарства, која сукцесивно приказује дуги низ догађаја из Тројанског рата - од приказа Пријама, подвига Ахила, Реса, Троила, тројанских жена у молитви, преко убиства Хектора, јунаштва Енеја, Мемнона и, коначно, Амазонки и Пентесилеја (-1.446-493). Епски приповедач предочава сложени артефакт у коме се сликарски и архитектонски идеалу сустичу. ${ }^{9}$ Час је да Вергилијев сасневач буде дозван - Рутилијев сан о Риму достиже свој врхунац управо у блиставој лепоти сакралне архитектуре, којом се, у исти мах, опредмећују естетски идеали и остварује блискост са вишим светом:

...non procul a caelo per tua templa sumus...

...Твојим храмовима благодарећи од небеса нисмо далеко... [...]

confunduntque vagos delubra micantia visus ipsos crediderim sic habitare deos.

Храмови расути блистањем својим помућују вид: богови сами, поверовао бих, у таквим домовима живе. ${ }^{10}$

9 О особеностима екфрастичког и на махове псеудо-сликарског поступка у Енеияи погл. Thomas 1981, Barchiesi 1997, Пилиповић 2013.

10 О своме йоврайку, 1.50, 1.95-96. Мој превод. 
Насупрот томе, за Вергилијев Рим-сан не везује се ни целовита урбана структура нити подробно описано архитектонско дело, већ само бритки осврт на благодети Цезаровог градитељства, део микронаратива у оквиру екфразе Енејиног штита:

...dis Italis votum inmortale sacrabat, maxuma tercentum totam delubra per urbem. Laetitia ludisque viae plausuque fremebant; ... те се и одужи бозима италским заветним даром бесмртним: триста он храмова изгради читавим градом. Амфитеатри одзвањају, улице, клицањем, пљеском. ${ }^{11}$

Највеличанственију Августову задужбину, храм Аполону Акцијском на Палатину ће песникова реч само на трен осветлити:

Ipse, sedens niveo candentis limine Phoebi..

Ено и Август, пред вратима заседа Фебовог храма блиставо белог... ${ }^{12}$

Утолико се снажније указује да идеалитет Рима не лежи на пољу архитектуре, ма како величанствена она била, нити уопште на пољу ичега материјалног. Блиставе грађевине које се у свести многих, међу њима и Рутилија Клаудија Наматијана, током миленијума, поистовећиване са престоницом света, за песника Енеuge имају само привидну вредност: пошто припадају, у онтолошком смислу, најнижем облику бивствовања, свој смисао црпу само из онога што симболизују, наговештавају или на шта упућују.

Спољашњи лик града тако нема значаја по себи самом, већ чини оквир у који се смештају трајније,

11 Енеияа 8.715-717. Прев. М. Пакиж

12 Eнеиga 8.720. Прев. М. Пакиж 
надтварне вредности: прва од њих је поредак. Иза спољашње, урбанистичке уређености, која се везује већ за најранију повест Рима, ${ }^{13}$ крије се унутрашњи поредак који се огледа у законитости, односно у хармонизованости коју стварају и одржавају правне норме, чиме се он разликује од остатка света, земног шара или не-града:

quis procul ille autem ramis insignis olivae sacra ferens? nosco crinis incanaque menta regis Romani primam qui legibus urbem fundabit... Ко ли је подаље онај? Што гранчицу маслине има, Приноси жртву? Препознајем косу и проседу браду! Римски је краљ и одредиће законе. Тиме ће нови Град утемељити; ${ }^{14}$

Сасневач прати великог сневача, сведочећи да је веза између Града над градовима и феномена закона дубоко укорењена у римски идентитет. Рутилије пева:

dumque offers victis proprii consortia iuris, urbem fecisti quod prius orbis erat. Поклонивши побеђенима удео у сопственим законима, створио си град тамо где пређе бејаше тек земни шар. ${ }^{15}$

\section{За Вергилија, као и за Рутилија, ${ }^{16}$ Рим-град се}

13 Дионисије из Халикарнаса (Римске стиарине 2.76. 539) поделу града на дистрикте приписује последњим римским краљевима, док карактеристична мрежа праволинијских улица, карда и декумана, наследују урбанистичку визију Хиподама из Милета и структуру војног логора.

14 Енеияа, 6.808-811.Прев. М. Пакиж.

15 О своме йоврайку, 1.65-66. Мој превод.

16 Рутилијева поема посебну пажњу поклања институцији римског Сената, који добија божанске одлике и предмет је разних читања - вид. Bruggisser 2011, где се разматра да ли постоји геније римског Сената који се може обоготворити, попут генија римског императора који је бивао деификован. 
преклапа са модерним појмом државне уређености. Унутрашњи његов поредак се претапа у умеће владања: своју хармонизованост, омогућену законима, Рим износи у свет, преноси свима другима и управо у томе лежи његов предодређеност за универзалну власт ${ }^{17}$.

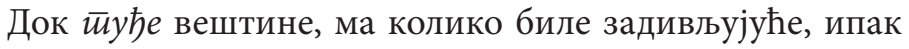
леже у домену предметног, тварног и перцептивног, самосвојно римско умеће лежи у надтварном домену односа међу људима и међу народима, у коме хијерархија рађа хармонију. Римско умећа владања је тога умеће стварања и одржавања поретка у свету:

..excudent alii spirantia mollius aera (credo equidem), vivos ducent de marmore vultus, orabunt causas melius, caelique meatus describent radio et surgentia sidera dicent: tu regere imperio populos, Romane, memento (hae tibi erunt artes), pacique imponere morem, parcere subiectis et debellare superbos.

Нежније други ће ковати бронзу, ко стварно да дише, Не сумњам да ће ко жива у мермеру вајати лица; Водиће парнице боље и боље ће цртачким штапом Небеске мене приказати, кад која излази звезда Ти ћеш пак, Римљанин, народе водити, памти ту дужност! Биће то твоје вештине: у миру да неметнеш закон, Покорне увек да штедиш, а силом да охоле сламаш! ${ }^{18}$

И Рим-Град, у ужем смислу, Roma-urbs, и Рим-народ, Roma-gens, консупстанцијални су са идеалним владаром: и у Eнеugu, као и у Еклоїама, тополошки и сотериолошки конструкт се стапају, ${ }^{19}$ али се и суштински обогаћују. Универзална власт, па чак ни свеопшта

17 О идеолошко-политичкој димензији слике Рима у Енеиgи вид. Pomathios 1987: 186-211, а особито Hardie 1986 : 303-326.

18 Енеияа, 6.847-853. Прев. М. Пакиж.

19 Вид. Енеияа 1.286-290. 
Сан о Риму - визија идеалног Града у Вергилијевом делу 335

хармонија, коју омогућава римско умеће владања нису саме себи циљ: Вергилијев Рим је, такође, и телеолошки конструкт у коме се конкретизује и актуализује сан о Златном добу:

Aspera tum positis mitescent saecula bellis; cana Fides, et Vesta, Remo cum fratre Quirinus, ura dabunt; dirae ferro et compagibus artis claudentur Belli portae;

Страшни ће ратови стати, наступиће векови благи, Верност оседела, Веста и Рем, тад уз брата Квирина, Делиће правду; закључаће гвожђа и засуни тешки Капије суровог Рата... ${ }^{20}$

Идеални владар, рођен у једном часу историјског тока, повешће ка застоју тога тока, ка престанку догађања:

huc geminas nunc flecte acies, hanc aspice gentem Romanosque tuos. hic Caesar et omnis Iuli progenies magnum caeli ventura sub axem. hic vir, hic est, tibi quem promitti saepius audis, Augustus Caesar, divi genus, aurea condet saecula qui rursus Latio regnata per arva Saturno quondam...

Овамо скрени поглед и овај сад погледај народ, Римљане своје. И Цезар је овде и редом сва лоза Јулијска што ће под небеске сводове високе доћи. То је, то је тај човек, за кога си чуо да кажу Август Цезар, од оца божанског - да ... златно ће доба донети Лацију опет, ко некад кад владаше Сатурн

Пољима... “21

20 Eнеиga 1.291-294. Прев. М. Пакиж.

21 Енеияа 6.788-794. Прев. М. Пакиж. 


\section{4. Елизијски Рим}

Спев посвећен оснивању Рима и као града, urbs, и као народа, gens, Eнеuga га осликава само у оквиру пролепси, наративних или екфрастичких искорака у будућност, међу којима кључно место заузима елизијско откровење ${ }^{22}$. Када буде закорачио преко прага раја, пред Енејом ће се појавити душе римских великана, које ће се тек родити, али предегзитентно већ јесу: еклектички спојена ${ }^{23}$ са неопитагорејском и платонистичком доктрином о сеоби душа, стоичка концепција предестинираности и судбинске предодређености обезбеђује савршено оруђе да се величанствена повест Рима, која је будућност за Енеју, а прошлост за његовог песника и све потоње читаоце, представи не као линеарни, већ као реверзибилни ток времена. Као љуштура своје језгро, Елизиј у себи носи повесни Рим: или, ако се вегетативна метафора обрне, може се рећи да повесни Рим изниче из елизијског као биљка из свога семена: управо таквом сликом ће Вергилијеву комплексну онто-есхатологију поједноставити позни сасневач његовог сна о Риму, Рутилије Клаудије Наматијан:

semina virtutum demissa et tradita caelo non potuere aliis dignius esse locis.

...семена врлина ниједно тло не беше достојније у себе, по налогу небеском, да прими... ${ }^{24}$

22 И Енејина визија и опис Елизија представљају примере екфразе, поступка који задобија посебне одлике у Вергилијевој поетици, о чему погл. Barchiesi 1997, Putnam 1998.

23 Филозофски еклектицизам је део свепрожимне Вергилијеве полифоничности. За општи увид у песников интертекстуални поступак упућујем на Thomas 2002; на српском језику Будимир - Флашар 1991: 285-331; о овом сегменту Le Bris 2001.

24 О своме йоврайку 1.9-10. Мој превод. 
Сан о Риму - визија идеалног Града у Вергилијевом делу 337

Међутим, Елизиј је есхатолошки, ${ }^{25}$ а надасве иматеријални простор: иматеријалност, која се садржи већ у самом појму станишта блажених душа, наглашена је и поетским органоном којим се описује и граничном егзистенцијом бића која га настањују. Будући да у фикционалном свету Енеиgе постоји само као дуга поворка хероја, који већ jecy у оностраности, али тек треба да се роде у овостраности ${ }^{26}$ - Рим се обестварује на сличан начин као и Елизиј. Град и у дословном и у симболичком смислу, Рим постоји у безвремности онога света и у будућности овога света, њихово оваплоћење је предестинирано, али ипак зависи од Енеје.

У свом идеализованом опису престонице света Рутилије спаја више књижевних традиција, како прозних, тако и поетских: традиције периегетике, екфразе, химнографије и епидеиктичке беседе, особито њенога субжанра под називом йохвала ipagy, laudatio urbis, а надасве је имплицитна химна богињи Роми. Врхунац поеме је и час у ком се лепота Рима-Роме претапа у алегоријски портрет:

erige crinales lauros seniumque sacrati verticis in virides, Roma, refinge comas. aurea turrigero radient diademata cono, perpetuosque ignes aureus umbo vomat! Подигни над витице своје ловоре и зеленим изданцима Изнова овенчај косу на светој глави! У златној дијадеми нек блиста круна од кула Вечне ватре златни штит нека бљује! ${ }^{27}$

25 О Вергилијевом подземном свету вид. Solmsen 1990, Negri 1992, Heuzé 1999.

26 О сложеном проблему метемпсихозе у Eнеugu, који у овом тексту остављам по страни, погл. Molyviati-Toptsis 1994, Harrison 1978, Luck 1973.

27 О своме йоврайку 1.115-118. Мој превод. 
Упркос богатом мултигенеричком предиву, Рутилије свој текст увек тка на великог августовског песника - што га и чини његовим незаменљивим сасневачем. Тек у поређењу са управо наведеним стиховима Вергилијев визија Рима обелодањује своје снохвате:

illa incluta Roma

imperium terris, animos aequabit Olympo, septemque una sibi muro circumdabit arces, felix prole virum: qualis Berecyntia mater invehitur curru Phrygias turrita per urbes laeta deum partu, centum complexa nepotes, omnis caelicolas, omnis supera alta tenentis. ... славни ће онај Рим, сине, владати земљом, а духом до олимпских висова стићи. Седам ће брегова једним опасати бедемом - срећан И благословен јунацима - као берекинтска Мајка, Када се с круном од кула кроз фригијске градове вози, Дичи се породом својим божанским, на стотине грли Унука који небеса настањују, просторе вишње. ${ }^{28}$

Лик богиње Роме, који одјекује рутилијевским стиховима, ${ }^{29}$ близнакиње Велике мајке, Кибеле, засењен је двоструком анагогијском сликом: најпре сликом града који се, духом, уздиже до олимпских висова, док се, телима својих грађана, запоседа земљин шар, а потом сликом деце Рима који се уздижу до небеса, поставши небожительи, caelicolae. ${ }^{30}$

Дубљи смисао вечности Рима, његове бескрајности у времену, лежи у потирању времени-

28 Eнеияа 6.781-787. Прев. М. Пакиж.

29 О томе вид. Reiss 2003.

30 Инспиративну анализу овог сегемента Енејине катабазе доноси Smith 2005: 85 passim. 
Сан о Риму - визија идеалног Града у Вергилијевом делу 339

тости саме. Идеални владар, херој-спаситељ, консупстанцијалан је Риму зато што, као и он, унутар света Eнеиgе не постоји, иако, баш као и Рим, предестинантно бивствује. Стварање Рима, коме је посвећена целокупна радња спева и сви напори Енеје, ${ }^{31}$ само су извођење у појавност и овостраност онога што на есенцијални, надпојавни начин, у оностраности већ јесиее: превођење ноуменалноі у фаиноменално. Или није баш тако? О нешто другачијем извођену говоре последњи стихови Шестог певања Eнеuge, градећи другачију везу између оног римског и оног ониричког. Као и реч Рим, и реч сан има два веома различита спектра значења: сан означава узмак од јаве, иреалитет у коме се вредности разигравају, размаштане и ослобођене; означава, међутим, и узмак од бивствености, иреалитет у коме се само постојање слама и копни.

Конструкт Рима, чија се вредност испрва описује само наговештајима, у Вергилијевом делу се постојано и све снажније открива као простор узнесења и трансонтичког спајања. У последњим стиховима Шестог певања Eнеuge, одмах након елизијског откровења, Рим се, међутим, предочава и као могуће привиђење ${ }^{32}$ и ониричка опсена. У часу када се показује сва његова надисторијска, анагогијска снага, разоткрива се и његова суштинска онтолошка ломљивост: ${ }^{33}$

31 О томе вид. Deproost 2001, Thomas 1992.

32 Драгоцен увид у зависност Вергилијевог текста од психичких категорија даје Thomas 1981: 33-73, 107-186.

33 Усуђујем се да читаоца упутим на много подробнију анализу овог важног сегмента Eнеuge у Пилиповић 2014, где ће наћи и додатну литературу. 
Sunt geminae Somni portae, quarum altera fertur cornea, qua veris facilis datur exitus umbris, altera candenti perfecta nitens elephanto, sed falsa ad caelum mittunt insomnia Manes. his ibi tum natum Anchises unaque Sibyllam prosequitur dictis portaque emittit eburna, ille viam secat ad navis sociosque revisit.

Две су капије сна, и једна је од њих од рога, Кажу, а излазе лако том капијом истинске сени; Друга је блиставо бела, од слонове тесана кости, Али су варљиви снови под небо што шаљу их дуси. Тако говорећи испрати Анхиз Сибилу и сина Те их слонокосном капијом пусти да отуда оду. ${ }^{34}$

Херој који спеву даје своје име, праотац, утемељитељ и спаситељ, заједно са пророчицом која га је повела ка дверима Елизија, пролазе не само кроз капију сна, већ кроз капију варљивих снова. Не само њихов онтолошки статус, већ статус свега шта су искусили тиме се из корена дестабилизује: да ли је и сам Рим, онакав какав је представљен у елизијском откровењу, до кога су заједничким стремљењима доспели Енеја и Сибила, ти пролазници кроз врата од слоноваче, такође можда само вартиви сан, falsum insomnium?

\section{5. Закључак}

Сан о Риму пролази кроз преображаје: од идеализованог фантазма, преко псеудо-профетског фантазма и профетске визије до ониричке визије. Усађен у два тополошка конструкта чија је веза са емпиријском стварношћу веома крхка, у Аркадију и у Елизиј, Рим је драгоцени засад у Вергилијевом свету од речи, можда и најдрагоценији, зато што му је много стваралачког

34 Енеияа 6.893-898. Прев. М. Пакиж. 
Сан о Риму - визија идеалног Града у Вергилијевом делу 341

труда поклоњено. Као сваки засад, сан о Риму живи односно мења се - расте ка својој величанствености и ка својој нестварности. Његова парадоксалност лежи у томе што се истовремено и уздиже и обестварује.

Могу ли се препознати неке постојане осе које прожимају све кључне видове сна о Риму на дугом путу од Еклоїa до Eнеuge? Тај пут води од магловите поредбене слике Прве еклоїе, у којој се могу рашчитавати метафоричка, симболичка, алегоријска значења, до помно разрађене и многослојне идеологеме, у Првом и Шестом певању Eнеugе, у којој саучествује историјско, политичко, чак ангажовано, онтолошко и есхатолошко. Сневани Рим, на том путу, остаје истодобно и тополошки и сотериолошки конструкт, као што чува функцију трансонтичке везе, спојнице два света.

Пут који прелази конструкт Рима не води, међутим, само од првих стихова Еклоїа до завршних речи Енеиgе, већ води такође од кийариса који продире у висине - ка

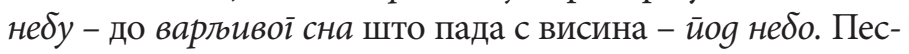
никова визија идеалног Града успиње ка аксиолошким врховима за којима би се ретко који уметник речи усудио да посегне - као што сведочи панегиричка поема његовог сасневача у овом огледу, Рутилија. Допире до Олимпа, небеса, бескраја у простору и времену, до новог, коначног, златног доба и до саме безвремености. Али, Вергилијева визија идеалног Града такође се и угиба тако дубоко како би се ретко који уметник речи усудио да сађе - ка привиду, варљивости, лажности. Да ли песник Енеиgе сан о Риму који снева предочава као истинит или као варљив, као бивствен или као небиствен, као остварење или као порицање смелих идеала? Кроз један од својих најдрагоценијих засада, Puм, коме је умео да прида бескрај, Вергилије показује и бескрајност сопствене поезије - која је недовршива јер се на упитаност коју носи у себи не може наћи коначан одговор. 
Извори

Rutilius Namatianus, Claudius. De reditu suo. The Latin Library The Miscellany. Веб. 11. 2107.

Vergilius Maro, Publius. Oeuvres. Texte latin, éd. Par F. Plessis et P. Lejay. Paris : Librairie Hachette, 1913. Штампано.

Вергилије Марон, Публије. Енеиgа. Превела Марјанца Пакиж. Београд: Федон, 2014. Штампано.

\section{Литература}

Barchiesi, Alessandro. „Virgilian narrative: ecphrasis“. Charles Martindale (ed.). The Cambridge companion to Virgil. Cambridge: Cambridge University Press, 1997. 271-282. Штампано.

Filoche, Christina et Nicole Boëls-Janssen. 2007. Lintertexte virgilien et sa réception: écriture, récriture et réflexivité chez Virgile et Rutilius Namatianus. Dijon. Штампано.

Bruggisser, Philippe. „Rutilius Namatianus et le génie du Sénat de Rome: le verdict d'une inscription de la ville de Rome (CIL VI 41378)“. Hermes 139/ 4 (2011) : 494-500. Веб. 11.2017.

Deproost, Paul-Augustin. „La marche initiatique d'Enée dans les enfers". Folia Electronica Classica 1 (2001). Веб. 2. 2014.

Hardie, Philip R., Virgil's Aeneid. Cosmos and Imperium, Clarendon Press, Oxford, 1986. Штампано.

Harrison, E. L. „Metempsychosis in Aeneid Six“. The Classical Journal 73/3 (1978): 193-197. Штампано.

Heuzé, Philippe. Enéide. Paris : Ellipses, 1999. Штампано.

Le Bris, Anne. La mort et les conceptions de l'au-delà en Grèce ancienne à travers les épigrammes funéraires. Etude d'épigrammes d'Asie mineure de l'époque hellénistique et romaine. Paris : L'Harmattan, 2001. Штампано.

Luciani, S., "Quelques remarques sur le vocabulaire du temps chez Virgile: ...dulcis moriens reminiscitur Argos". Bulletin d'Association Guillaume Budé 48 (1997) : 117-137. Штампано.

Luck, Georg. „Virgil and the Mystery Religions“. The American Journal of Philology 94/2 (1973): 147-166. Ве6. 3. 2014. 
Сан о Риму - визија идеалног Града у Вергилијевом делу 343

Molyviati-Toptsis, Urania. „Vergil's Elysium and the OrphicPythagorean Ideas of After-Life“. Mnemosyne 47/1 (1994): 33-46. Штампано.

Negri, Angela Maria. „La psyché chez Virgile: conception et terminologie“, Bulletin d'Association Guillaume Budé 3 (1992): 272-295. Штампано.

Norwood, Gilbert. „Rutilius Claudius Namatianus“. Phoenix 1 (1947): 36-41. Веб. 11.2017.

Pomathios, Jean-Luc. Le pouvoir politique et sa représentation dans l'Enéide de Virgile. Bruxelles : Latomus - Revue d'Etudes Latines, 1987. Штампано.

Putnam, Michael. Virgil's Epic Designs: ekphrasis in the Aeneid. New Haven: Yale University Press, 1998. Штампано.

Reed, Nicholas. „The Gates of Sleep in Aeneid 6“. The Classical Quarterly 23/2 (1973): 311-315. Штампано.

Reiss, M. „Rutilius Claudius Namatianus: Laudes Romae, als Ergänzung zu Vergils Aeneis“. Die Alten Sprachen in Unterricht 50 (2003): 18-54. Веб. 11.2017.

Roberts, Michael. „Rome Personified, Rome Epitomized: Representations of Rome in the Poetry of the Early Fifth Century“.The American Journal of Philology 122/4 (2001): 533-565. Веб. 11.2107.

Smith, Riggs Alden. The Primacy of Vision in Virgil's Aeneid, Austin: University of Texas Press, 2005. Штампано.

Solmsen, Friedrich. „The World of the Dead in Book 6 of the Aeneid“. S.J. Harrison (ed.). Oxford Readings of the Vergil" «Aeneid». Oxford: Oxford University Press, 1990. 208-223. Штампано.

Thomas, Joël. Structures de l'imaginaire dans l'Enéide. Paris : „Les Belles Lettres“, 1981. Штампано.

Thomas, Joël, „Lespace de l'Enéide ou la quête du sens“. Bulletin d'Association Guillaume Budé 3 (1992): 253-261. Штампано.

Thomas, Richard. Reading Virgil and His Texts. Studies in Intertextuality. Ann Arbor: The University of Michigan Press, 2002. Штампано.

Будимир, Милан и Мирон Флашар. Преїлеg римске кюижев-

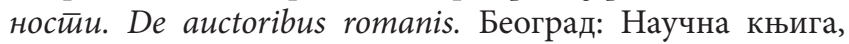
1991. Штампано.

Пилиповић, Јелена. „Језик светлости. Поетичке аналогије 
Платонове Државе и Вергилијеве Енеиgе“. Зоран Пауновић и Биљана Дојчиновић (ур.). Параgиіме, уйищаји, рецейщија. Београд: Филолошки факултет, Београд, 2013. 185-196. Штампано.

Пилиповић, Јелена. „Porta eburna - Дијалог са Хомером као средство онтолошке игре у Вергилијевој Енеияи“. Ксенија Марицки-Гађански (гл.ур.) Ант̄ика и савремени

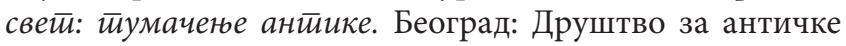
студије Србије, 2014. 307-316. Штампано.

Jelena Pilipovic

\section{DREAM ABOUT ROME. VISION OF IDEAL CITY IN VERGIL'S POETRY}

\section{Summary}

The paper offers a hermeneutical approach to the construct of Rome in the Eclogues and the Aeneid. Closely related to the politicological and eschatological conceptions of the Augustan circle, Vergil's vision of the Rome is also deeply rooted in his quest for the ideal. Two main aspects are discernable, but not actually dividable: the notion of Rome as a City, Roma-Urbs, is melted into the notion of Rome as a people-tribe, Roma-gens. Although primarily a topological entity, from the very first Vergil's text, the Eclogue 1, the construct Rome is organically united with the ideal savior, the godlike leader figure. The topological aspect is thus undividable from the soteriological one. The paper aims at exploring the inner dynamics of this complex and multi-layered creation of Vergil's in order to reveal its peculiarities and to trace the roots of its immense influence.

Key-words: ideal, ideological, engaged poetry, oniric, eschatology, P. Vergilius Maro, Rutilius Claudius Namatianus. 